THE ANNALS OF "DUNĂREA DE JOS" UNIVERSITY OF GALATI

FASCICLE III, 2019, VOL. 42, NO.2, ISSN 2344-4738, ISSN-L 1221-454X

ELECTROTECHNICS, ELECTRONICS, AUTOMATIC CONTROL, INFORMATICS

Article DOI: https://doi.org/10.35219/eeaci.2019.2.05

\title{
CHOOSING THE CONTROL AND DATA ACQUISITION SYSTEM USING DAQ-TOOL APPLICATION
}

\author{
Ciprian Daniel Bălănuță ${ }^{1}$, Gelu Gurguiatu ${ }^{1}$, Alexandru Dușa ${ }^{1}$, Ion Voncilă ${ }^{1}$, \\ Cătălin Puiu' ${ }^{2}$ Daniel Necula ${ }^{2}$
}

${ }^{1}$ University ,Dunărea de Jos” of Galați

${ }^{2}$ ELECTRO-TOTAL

\begin{abstract}
Energy efficiency is one of the pillars of sustainable development. In this context, the power quality is an indicator for the assessment of the electrical energy efficiency. Active power filters (APF) are a solution to improve the power quality. This paper presents a software instrument, called Daq-tool, aimed to assist designers in selecting the appropriate control system for the APF, starting from a set of specific requirements. This application was developed in the project: „Knowledge Transfer Regarding the Energy Efficiency Increase and Intelligent Power Systems" (acronym CRESC-INTEL).
\end{abstract}

Keywords: Energy efficiency, Power quality, active power filter, electronic application, APF control systems.

\section{INTRODUCTION}

The diversification of the loads powered from the grid - most of them nonlinear - result in important harmonic and reactive regimes, along with unbalances in three-phase systems. Typical examples of such loads are: adjustable speed electric drives, high power electric furnaces, DC distribution networks, systems for the conversion of unconventional energies, and many others. Nonlinear loads impact the entire grid, from generation, transport, and final consumer, producing significant negative effects like reducing the capacity to produce active power usable, reducing the efficiency of the energy transmission, and - in some cases- making the entire grid unusable.
Mitigating or canceling these effects can be achieved in several ways. A simple, inexpensive and verifiable way to do this is to use conventional passive filters $\mathrm{L}+\mathrm{C}$ and/or $\mathrm{C}$. This solves in part the problem by reducing the content of harmonics and improving the power factor, but this type of systems has mostly discontinuous operation, and a modest dynamic. Besides these drawbacks, there is also a risk of resonance phenomena when using passive filters.

A more efficient solution to overcome these negative effects is to use active power filters (APF), which are more expensive, but have better performances and offer the means to reduce multiple negative effects with the same device. It is not necessary to use different devices for each type of negative effect, but only one device with a well adapted control algorithm. The active power filters are very well 
covered in literature: see (Akagi, 2017), (H. Kouara, 2014), (Ramandeep Singh, 2018).

Starting from the effects or from the ensemble of effects which must be reduced/canceled it have to be chosen an adequate data acquisition and control system.

It is very well known that one of the most important subsystems from an APF is the data acquisition and control system (DAQ). To achieve good results, it is very important to have a well selected DAQ system. On the market nowadays there are a lot of producers offering a wide variety of DAQ solutions ready to be used in the construction of an APF.

However, the active power filter is requiring special data acquisition and control system (DAQ) to be used in the APF construction, considering the variety of APF (three phase - three wire active power filters, three phase - four wire active power filters, monophase active power filter, correction of a negative effect or for an ensemble of effects etc.)

It is important to know what are the limits of the entire APF as well as the limits of the DAQ system used to control the APF.

Bringing clarifications to these aspects is one of the objectives of the project "Knowledge transfer regarding the energy efficiency increase and intelligent power systems", (acronym CRESCINTEL), and this paper is intended to support this goal. The overall objective of the project is to increase the transfer of technological knowledge and staff with skills between "Dunarea de Jos" University in Galati and SME that develop electricity business with demanded market outcomes. The project aims at establishing partnerships between "Dunarea de Jos" University in Galati and enterprises interested in acquiring knowledge, including abilities and competencies to increase energy efficiency and intelligent power systems in order to obtain a competitive solution, for an intelligent Active Power Filter (APF).

There is proposed an electronical application called DAQ-tool which aims is to facilitate the chosen of a DAQ system for an APF considering the most relevant inputs.

\section{DAQ SYSTEM}

To choose the data acquisition and control system (DAQ system) for an active power filter (APF) there are a few important aspects to be considered:

- System type - The system type can be as following: Single-phase, Three-phase without neutral wire, Three-phase with neutral wire;
- APF type - Single-phase with two arms, three-phase with three arms, three-phase with three arms and midpoint, three-phase with four arms.

Considering the two parameters System type and $A P F$ type there are defined the following:

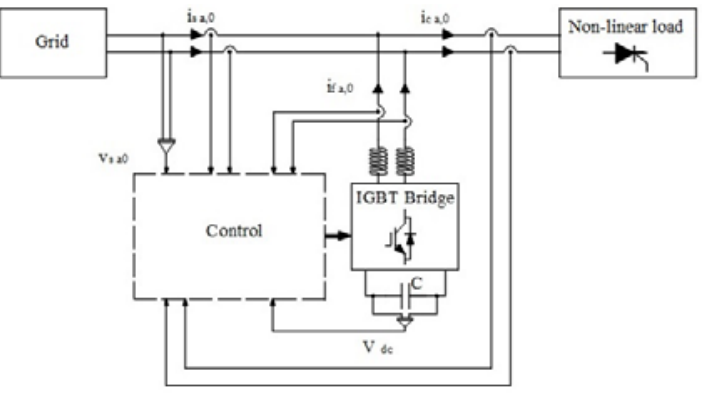

Fig.1 Single-phase/ Single-phase with two arms

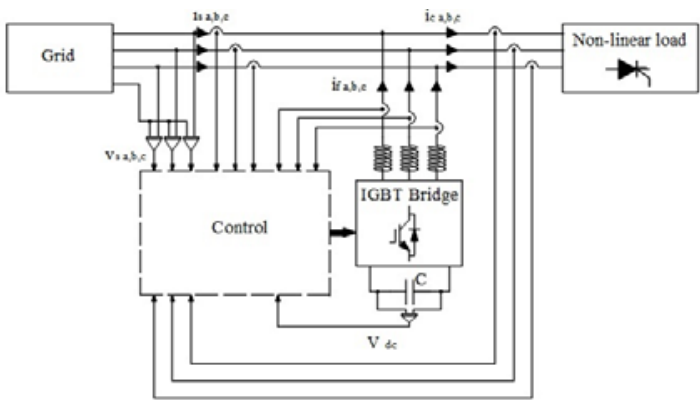

Fig.2 Three-phase without neutral wire/ three-phase with three arms

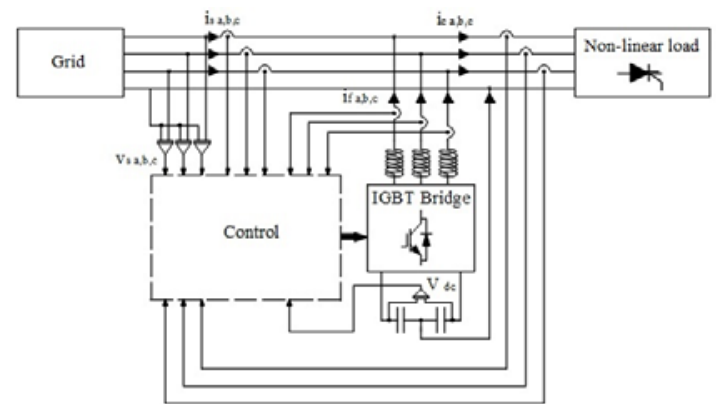

Fig.3 Three-phase with neutral wire/ three-phase with three arms and midpoint

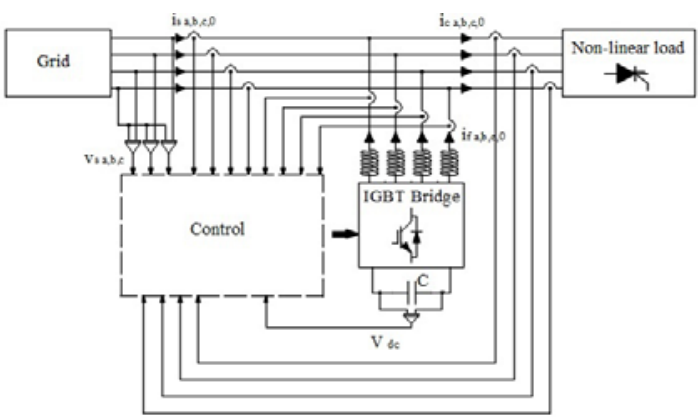

Fig.4 Three-phase with neutral wire/ three-phase with four arms 
Control Strategy - As it was presented in (Gelu Gurguiatu, 2019) a wide variety of control strategies can be considered in order to improve different power quality indicator. Thus, there was considered the following control strategies:

$\begin{array}{ll}\text { o } & \text { PQ control strategy } \\ \text { o } & \text { DQ control strategy } \\ \text { o } & \text { Indirect control strategy (CI) } \\ \text { o } & \text { Polluting component separation } \\ & \text { (SCP-FOB) control strategy } \\ \text { o } & \begin{array}{l}\text { Polluting component separation } \\ \text { (SCP-FTJ) control strategy }\end{array} \\ \text { o } & \text { Maximum control strategy }\end{array}$

Also, there is a wide a variety of power quality indicator who can be improved: Harmonic current; Reactive current; Load balancing; Neutral current; Harmonic voltages; Voltage regulation; Balancing tensions; Flicker; Voltage drops and gaps; Harmonic and reactive currents; Harmonic and reactive currents, load balancing, Harmonic currents, zero, reactive, load balancing; Harmonic voltage, voltage regulation; Harmonic voltage, voltage regulation, Flicker, drops, gaps; Harmonic currents and voltages, Reactive and harmonic current, harmonic voltage, voltage regulation; Balancing and regulation voltage, Reactive current, load balancing; Neutral reactive current, load balancing; Harmonic, reactive current, voltages balancing; Harmonic current, load balancing; Harmonic, neutral current, voltages balancing.

Using different control strategies, the power quality indicators can be improved with better or worse results. So, it is very important to choose the adequate control strategy in order to obtain best possible results as it is presented in (Gelu Gurguiatu, 2019).

The APF topology it is also important to be known when it is chosen the DAQ system. Starting from the APF topology and from the control algorithm it is defined the following: necessary number of analog inputs, necessary number of analog outputs, necessary number of digital inputs, necessary number of digital outputs, Flip-Flops, Slice LUT, Block RAMs etc.

DAQ system it is very well related to the control strategy, topology but also with the algorithm. It is important to know exactly which hardware resources are necessary to execute the entire algorithm in a certain period.

Related to the hardware resources there are presented in the following 2 tables hardware parameters for three-phase - three wire and for three-phase with three arms and midpoint topology. The presented results are considering the control strategy as well.
The FPGA characteristics (Flip-Flop, Slice and BlockRAMs) was determined by deploying each algorithm control on an Xilinx processor.

\begin{tabular}{|c|c|c|c|c|c|c|}
\hline \multirow[b]{2}{*}{$\begin{array}{l}\text { Control } \\
\text { Strategy }\end{array}$} & \multirow[b]{2}{*}{$\begin{array}{l}\text { No. } \\
\text { AI }\end{array}$} & \multirow[b]{2}{*}{$\begin{array}{l}\text { No. } \\
\text { AO }\end{array}$} & \multirow[b]{2}{*}{$\begin{array}{l}\text { No. } \\
\text { DIO }\end{array}$} & \multicolumn{3}{|c|}{ FPGA } \\
\hline & & & & $\begin{array}{l}\text { Flip- } \\
\text { Flops }\end{array}$ & $\begin{array}{l}\text { Slice } \\
\text { LUT }\end{array}$ & $\begin{array}{l}\text { "Block } \\
\text { RAMs }\end{array}$ \\
\hline Sec pos & 10 & 4 & 6 & 14750 & 23979 & 180 \\
\hline $\begin{array}{l}\text { SCP- } \\
\text { FOB }\end{array}$ & 10 & 4 & 6 & 13767 & 25162 & 216 \\
\hline MAX & 10 & 4 & 6 & 18566 & 25980 & 180 \\
\hline PQ & 10 & 4 & 6 & 12693 & 21913 & 180 \\
\hline$\overline{\mathrm{DQ}}$ & 10 & 4 & 6 & 16134 & 23970 & 180 \\
\hline $\begin{array}{l}\text { SCP- } \\
\text { FTJ }\end{array}$ & 10 & 4 & 6 & 14948 & 25260 & 216 \\
\hline CI & 7 & 4 & 6 & 11565 & 19916 & 180 \\
\hline
\end{tabular}

Table 2 -Hardware for DAQ in three-phase - with three arms and

\begin{tabular}{|c|c|c|c|c|c|c|}
\hline \multirow{2}{*}{$\begin{array}{l}\text { Control } \\
\text { Strategy }\end{array}$} & \multirow[b]{2}{*}{$\begin{array}{l}\text { No. } \\
\text { AI }\end{array}$} & \multirow[b]{2}{*}{$\begin{array}{l}\text { No. } \\
\text { AO }\end{array}$} & \multirow[b]{2}{*}{$\begin{array}{l}\text { No. } \\
\text { DIO }\end{array}$} & \multicolumn{3}{|c|}{ FPGA } \\
\hline & & & & $\begin{array}{l}\text { Flip- } \\
\text { Flops }\end{array}$ & $\begin{array}{l}\text { Slice } \\
\text { LUT }\end{array}$ & $\begin{array}{l}\text { "Block } \\
\text { RAMs }\end{array}$ \\
\hline Sec pos & 10 & 4 & 6 & 14750 & 23979 & 180 \\
\hline $\begin{array}{l}\text { SCP- } \\
\text { FOB }\end{array}$ & 10 & 4 & 6 & 13767 & 25162 & 216 \\
\hline MAX & 10 & 4 & 6 & 18566 & 25980 & 180 \\
\hline PQ & 10 & 4 & 6 & 12693 & 21913 & 180 \\
\hline DQ & 10 & 4 & 6 & 16134 & 23970 & 180 \\
\hline $\begin{array}{l}\text { SCP- } \\
\text { FTJ }\end{array}$ & 10 & 4 & 6 & 14948 & 25260 & 216 \\
\hline CI & 7 & 4 & 6 & 11565 & 19916 & 180 \\
\hline
\end{tabular}

\section{DAQ-TOOL APPLICATION}

DAQ-tool is an electronically application developed to be used as a tool to choose the right system for data acquisition and control in construction of an APF. The application is developed considering the principles presented before and is a simple tool to be used by any electrical engineer developing an intelligent power solution respectively an APF.

First of all, it has to be done a study concerning the consumer, to identify exactly the value for each power quality indicator. After that, it has to establish the power quality indicator or the set of them to be improved. In the same time the topology and the control strategy has to be established. Using these defined conditions it can be used DAQ-tool application to choose the right DAQ system which is the brain of APF.

For example, if we have a three-phase without neutral system, where the main power quality indicator to be improved is THDi and we want to realize a three phase $\mathrm{APF}$, then we can use an indirect control strategy. Using those conditions DAQ-tool application is calculating the following parameters for the DAQ system to be used in APF construction as the minimal necessary value:
0 No. AI: 7
o No. AO: 4
o No. DIO: 6 
THE ANNALS OF "DUNĂREA DE JOS" UNIVERSITY OF GALATI

FASCICLE III, 2019, VOL. 42, NO. 2, ISSN 2344-4738, ISSN-L 1221-454X

0 FPGA:

O Flip-Flops: 11565

o Slice LUT: 19916

o Block RAMs: 180

Also, considering the devices available on the market, DAQ-tool recommends a number of seven devices from different producers, which can be used to build the APF.

\begin{tabular}{|c|c|c|c|c|c|c|c|}
\hline 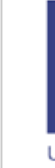 & $\begin{array}{l}\star^{\star}{ }^{\star}{ }^{\star} \star^{\star} \star^{\star} \\
\text { UNIUNEA EUROPEANA }\end{array}$ & & OLE & 1. & & Instrumente & Structurale \\
\hline & $\begin{array}{l}\text { Autoritatea Națională pentru Cercetare } \\
\text { Program Operațional Competitivitate - } \\
\text { Acțiune 1.2.3 Parteneriate pentru trans } \\
\text { Program cofinanțat din Fondul Europear } \\
\text { Titlu proiect: Transfer de cunoști } \\
\end{array}$ & $\begin{array}{l}\text { Stiințific } \\
\text { Axa } 1 \\
\text { fer de cu } \\
\text { n de Dezv } \\
\text { nțe privir }\end{array}$ & $\begin{array}{l}\text { și Inovare } \\
\text { ștințe } \\
\text { tare Regional } \\
\text { I creșterea e } \\
\text { CRESC-IN }\end{array}$ & $\begin{array}{l}\text { cientei energ } \\
\text { TEL }\end{array}$ & $\begin{array}{l}\text { ID/Cod My SMIS: P } \\
\text { Nr. contract: } 12 / 0 \\
\text { etice si sisteme in }\end{array}$ & $\begin{array}{l}40 \_340 / 10580 \\
1.09 .2016 \\
\text { teligente de pu }\end{array}$ & itere \\
\hline & & & Daq- $t$ & & & & \\
\hline & System type & & & & & the & 1. -linear lood \\
\hline & Three-phase without neutral wire & & & & & & \\
\hline & APF type: & & & & $\frac{1}{10 B T B r}$ & & \\
\hline & Three-phase with three arms & & & & Cottrol & & \\
\hline & Control Strategy: & & & & & & \\
\hline & $\mathrm{Cl}$ (Controlul indirect) & & & & & & \\
\hline & & & inimum rec & uirements & & & \\
\hline & 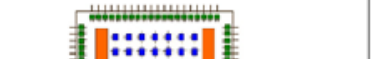 & & & & & FPGA & \\
\hline & 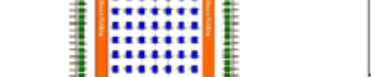 & INO. Al & INO. AU & NO. DIU & Flip-Flops & Slice LUT & $\begin{array}{c}\text { Block RAMs } \\
\text { kbits }\end{array}$ \\
\hline & - & 7 & 4 & 6 & 11565 & 19916 & 180 \\
\hline & & & dware rec & mandation & & & \\
\hline & & & & & & FPGA & \\
\hline No. & Name & No. Al & No. AO & No. DIO & Flip-Flops & Slice LUT & $\begin{array}{c}\text { Block RAMs } \\
\text { kbits }\end{array}$ \\
\hline 1 & X3-SD & 16 & 16 & 22 & 17280 & 153600 & 432 \\
\hline 2 & X3-SD16 & 16 & 16 & 22 & 33280 & 33280 & 1512 \\
\hline 3 & X3-Servo & 12 & 12 & 22 & 33280 & 33280 & 1512 \\
\hline 4 & X3-2M & 12 & 12 & 22 & 33280 & 33280 & 1512 \\
\hline 5 & X3-10M & 8 & 8 & 22 & 33280 & 33280 & 1512 \\
\hline 6 & MicroLabBox (Xilinx Kintex $^{\circledR}-7$ & 32 & 16 & 48 & 407600 & 50950 & 16020 \\
\hline 7 & OP4510 RT-LAB / RCP / HIL & 16 & 16 & 32 & 407600 & 50950 & 16020 \\
\hline 8 & & & & & & & \\
\hline 9 & & & & & & & \\
\hline 10 & & & & & & & \\
\hline 11 & & & & & & & \\
\hline 12 & & & & & & & \\
\hline 13 & & & & & & & \\
\hline 14 & & & & & & & \\
\hline 15 & & & & & & & \\
\hline & & & & & & & \\
\hline & & & & & & & \\
\hline & & & & & & & \\
\hline
\end{tabular}

(c) 2018 - CRESC-INTEL Universitatea „Dunărea de Jos” din Galați

Fig. 5 The DAQ-tool application interface 
THE ANNALS OF "DUNĂREA DE JOS" UNIVERSITY OF GALATI

FASCICLE III, 2019, VOL. 42, NO. 2, ISSN 2344-4738, ISSN-L 1221-454X

\section{CONCLUSIONS}

We presented the DAQ-tool application developed in the context of the project "Knowledge transfer regarding the energy efficiency increase and intelligent power systems". The DAQ-tool is one of the five tools developed in the mentioned project (Ptool, C-tool, M-tool and FAP-tool). All of the applications are designed to help the APF construction, each of them offering the possibility to design the most important subsystems of an APF.

DAQ-tool is useful for the engineers who are developing active power filters. This application considers all the important aspects in APF construction. The most important aspects considered are: System type, APF type, Control Strategy and is offer the information about the minimal requirement from the DAQ system: number of analog inputs, number of analog outputs, number of digital inputs and outputs and also information about the FPGA like: flip-flops, slice LUT, Block RAMs.

DAQ-tool can be improved in order to have a bigger database with more DAQ system producers and also in order to be up-dated after an important number of experimental validations.

\section{REFERENCES}

Akagi, H. W. (2017). Instantaneous power theory and applications to. John Wiley \& Sons.

Gelu Gurguiatu, C. D. (2019). Active power filter control strategy choosing by M-tool application. Galati: The 6th International symposium on electrical and electronics engineering. doi:978-1-7281-29068/19/\$31.00 C2019 IEEE

H. Kouara, H. L. (2014). Comparative Study of Three Phase Four Wire Shunt Active Power Filter Topologies based Fuzzy Logic DC Bus Voltage Control. International Journal of Energy, Information and Communications Vol.5, Issue 3.

Ramandeep Singh, E. B. (2018). RamandeePower quality improvement in three phase generation system using shunt active power filters. International Journal of Engineering Sciences \& Research Technology, DOI: 10.5281/zenodo.1305828. 